\title{
Health system preparedness in Pakistan for crisis management: a cross-sectional evaluation study
}

Zia Ul-Haq, ${ }^{1,2}$ Basharat Hussain Shah, ${ }^{1}$ Mohammad Ardakani, ${ }^{3}$ Saeed Akbar Khan, ${ }^{3}$ Saleem Muhammad, ${ }^{5}$ Saeed Farooq, ${ }^{4}$ Sardar Hayat Khan ${ }^{3}$ and Qudsia Huda $^{6}$

${ }^{1}$ Institute of Public Health and Social Sciences, Khyber Medical University, Peshawar, Pakistan. ${ }^{2}$ Institute of Health and Wellbeing, University of Glasgow, Glasgow, United Kingdom. ${ }^{3}$ World Health Organization, Islamabad, Pakistan. ${ }^{4}$ Primary Care and Health Sciences, University of Keel, Keel, United Kingdom. ${ }^{5}$ Gomal Medical College, Dera Ismail Khan, Pakistan. ${ }^{6}$ World Health Organization, Geneva, Switzerland. (Correspondence to: Zia Ul-Haq: drzia@kmu.edu.pk; zia.ulhaq@glasgow.ac.uk).

\begin{abstract}
Background: The World Health Organization (WHO) has strongly advocated health systems' preparedness for effective management of crisis situations globally for more than two decades. Pakistan is known for its high vulnerability to hazards and lack of coping and adaptive capabilities. Health systems' preparedness for locales with such high-risk profile is essential, yet there is a dearth of studies addressing the status of such preparedness in the country.

Aims: This study aimed to assess the status of preparedness of health-system components for crisis management in the most disaster prone districts of Pakistan.

Methods: A purposive sample of 12 of the most disaster prone districts in two provinces of Pakistan was evaluated for preparedness using the WHO's toolkit for assessing health-system capacity for crisis management. Six core functions of the Health Systems Framework, with a total of 229 indicators, were evaluated at the district management as well as secondary and tertiary health care facilities level. Proportions of indicators prepared were calculated and preparedness was classified as Acceptable ( $\geq 66 \%)$, Partial $(36-65 \%)$ or Inadequate $(\leq 35 \%)$.

Results: Seventy-two percent, 95\% Confidence Interval [46.0, 90.0] of indicators in these most vulnerable districts were evaluated as partially or inadequately prepared for appropriate management of crises. Even the highest scoring core function, Leadership and Governance was partially prepared with a score of 53.6\% $(52.4,54.9)$. Process elements were found to be less prepared compared with structure components.

Conclusions: Federal level strategic planning, implementation, management and follow-up aimed at ensuring health-systems' preparedness need to be reviewed and strengthened.

Keywords: Disaster preparedness, crisis management, health system, health risk, hazard, Pakistan

Citation: Ul-Haq Z; Shah BH; Ardakani M; Akbar Khan SA; Muhammad S; Farooq S; et al. Health system preparedness in Pakistan for crisis management: a cross-sectional evaluation study. East Mediterr Health J. 2019;25(8):553-561. https://doi.org/10.26719/emhj.18.072

Received: 24/12/17; accepted: 12/07/18

Copyright (C) World Health Organization (WHO) 2019. Some rights reserved. This work is available under the CC BY-NC-SA 3.0 IGO license (https:// creativecommons.org/licenses/by-nc-sa/3.o/igo).
\end{abstract}

\section{Introduction}

Health crisis is a blanket term referring to any event with a potentially momentous impact on human health in a population, including disastrous situations resulting from natural, technological, societal, and other sources (1). In spite of different causal dynamics, all such eventualities present similar challenges to health systems, a fact reflected in the World Health Organization's (WHO) 'all-hazards' approach towards preparedness for responding to them, enabling a unified mechanism for their effective management (2). More than 1.5 billion people have been affected by crises over the last decade, especially the vulnerable groups including children and women (3), incurring economic losses in excess of US\$ 1.3 trillion (4). Globally, an average of 110 ooo people died annually from natural or technological disasters during 2004-2013, not to mention the burden of injuries, illnesses, and psychological trauma $(5,6)$.

South Asia, harbouring more than a fifth of the world's population, ranks second lowest among the world regions (after Sub-Saharan Africa) in the human development index, life expectancy at birth, expected and mean years of schooling, and gross national income per capita (7). The region is especially prone to disasters because of its geo-climactic characteristics, having the fastest exposure growth rate in the world, 3.5\% per year, with significant increase in the risk of disasters projected over the next two decades. More than 600 million people live along the 2200 kilometre-long geological fault line across the Himalayan belt where, in addition to earthquakes, the threats include avalanches and glacial lake outburst floods, while droughts, floods and cyclones originating in the Bay of Bengal and the Arabian Sea affect the lowlands (8). Moreover, the region is home to many tenacious conflicts including insurgencies, ethnic tensions, and sectarian clashes with potential for further escalation (9).

Pakistan, comprising 156 districts in five provinces and a population of 207 million in 2017 (10), expected to reach more than 295 million by 2050 (11), has been in the midst of a vicious cycle of violence with the resulting mass casualties for more than two decades, added to the natural disasters taking their toll (12-14). The country is 
known to be in the very high to high risk category in its lack of coping and adaptive capabilities as well as in its vulnerability to hazardous situations $(1,15)$. Conservative estimates put the violence-related death toll for the country at more than 62000 since 2003 (16), while natural disasters over the last decade have affected more than 50 million people, causing more than 80000 deaths and economic losses estimated at US $\$ 25.5$ billion (17). The December 2005 earthquake alone cost more than the collective development aid of the previous three years put together (18). Disasters result from a combination of exposure, vulnerability and the systems' lack of capacity to cope (19). The need for multisectoral coordination for effective management of relief as well as for reduction of disaster risk has been felt for a long time. The United Nations General Assembly designated the 1990s as International Decade for Natural Disaster Reduction (IDNDR) (20). In order to continue the implementation of International Strategy for Disaster Reduction (ISDR) in the new century, the United Nations Office for Disaster Risk Reduction (UNISDR) was created in December 1999 (21). UNISDR defines its goal as "reducing disaster risks through systematic efforts to analyze and reduce the causal factors of disasters", emphasizing the role of preemptive readiness for managing natural hazards (22).

Preparedness (1) is vitally important for all emergency response systems (23) and for locales characterized by high levels of insecurity and uncertainty, efforts aimed at ensuring preparedness should be proportionately robust. In spite of the country's marked vulnerability to potential disasters, there is a dearth of studies aimed at assessment of preparedness for handling crises in Pakistan. On 21 June, 2018, PubMed search for preparedness and (evaluation or assessment) and (health system) and Pakistan in title did not return any results.

Pakistan's health system consists of primary, secondary, and tertiary care levels. Basic health units and rural health centres are the major primary care facilities caring for $10000-15000$ and $25000-50000$ population respectively. Secondary care facilities include Tehsil and District headquarter hospitals catering for $100000-$ 300000 and 1-2 million individuals respectively. There are tertiary care health facilities at provincial level, some of which are teaching hospitals as well (24). National Disaster Management Authority, National Health Emergency Preparedness \& Response Network and the Ministry of National Health Services, Regulations \& Coordination are some of the organizations involved in disaster management in Pakistan. The 2017 National Action Plan for Disaster Risk Management details the national, provincial, and district levels of disaster management infrastructure in the country, advocating progress monitoring, review and follow up (25).

\section{Study aim}

The objective of this study was to address the lack of published information regarding the state of health system preparedness for crisis management in the most vulnerable areas of Pakistan.

\section{Methods}

A purposive sample of 12 of the most disaster prone districts from Khyber Pakhtunkhwa and six from Punjab was selected by the WHO Pakistan office, and public health professionals from Khyber Medical University, Peshawar, based on risk stratification by the National Disaster Management Authority (26), the relevant Departments of Health, and field experience of the core team members in Pakistan. Khyber Pakhtunkhwa, with an area of 74521 square kilometres and population density of 259 per square kilometre, carries a very high risk profile. Punjab covers an area of 205344 square kilometres and is the most densely populated of the five provinces of Pakistan, with a population density of 536 per square kilometres. Preparedness for natural or manmade, predictable or unpredictable disasters (24) at district management as well secondary and tertiary health care delivery facilities was assessed using indicators documented in the toolkit published by the WHO Regional Office for Europe (EURO) in 2012 (27). Benchmark cutoffs were adopted from previous such assessments in the European Union using the same instrument (28). Analysis of published studies regarding disastrous situations from locales as diverse as the Caribbean, Africa, North America, Europe, Pakistan and Japan has shown that actual experience "supports the content and value of the WHO toolkit" (29).

The toolkit, pilot tested in several countries, covers the six core functions of WHO Health Systems Framework: Leadership and Governance; Health Workforce; Medical Products, Vaccines, and Technology; Health Information; Health Financing; and Service Delivery. The content is organized in a hierarchical fashion with different number of key components within each core function, with a total of 16 key components, several essential attributes within each key component, a total of 51 essential attributes and multiple Indicators within each essential attribute, a total of 229 indicators. Documentation (30) consists of coding an indicator at one of three levels of preparedness: Not prepared (0); Partially Prepared (1); and Fully Prepared (2). A perfect score of 2 on each indicator would render a total score of 458 for each of the 18 districts. Conformity scores are calculated as proportions of achieved scores out of the maximum achievable at different levels of health system hierarchy as well as that of the evaluation structure of the toolkit, i.e. two times the number of indicators assessing the relevant level; conformity scores are then categorized based on cutoffs described below.

Assessment of preparedness was done at district health management level, responsible for primary healthcare, and at secondary and tertiary healthcare facilities. Three tertiary care and nine secondary care hospitals from Khyber Pakhtunkhwa and six secondary care hospitals from Punjab were included in the study. As the country was not in a crisis situation at the time of the study, the evaluation covers inter-disaster and health sector preparedness phases (25).

After approval by the Ethical Review Board of Khyber Medical University, the Coordination Group, 
consisting of members from WHO, the two provincial ministries of health, and Khyber Medical University, formed assessment teams consisting of personnel with experience in the relevant domains. The assessment teams were trained in the evaluation of each component of the toolkit by the relevant resource persons, according to the user manual for the toolkit (2). In order to ensure a unified evaluation process, evaluators were observed by the resource persons during mock interviews and advised till process consistency was ascertained. The teams met and interviewed district health officers, hospital medical superintendents, and heads of emergency departments of selected hospitals for the relevant information from September 2016 to February 2017. Assessment forms were filled by evaluators while the key person was being interviewed, having signed written informed consent. Data were entered in Microsoft Excel ${ }^{\circledR} 2010$ Spreadsheet, exported to Stata version 14 for analysis (31).

Means and Standard Deviations (SD) are reported as summary measures for interval-ratio scale variables. Proportions for categorical variables are reported as percentages. Two group comparisons of scores are done using t-tests while multiple group comparisons are done using Kruskal-Wallis test. Conformity scores are categorized as inadequately prepared (score $\leq 35 \%$ ), partially prepared (36-65\%), or acceptable (66-100\%) (28). Ninety-five percent confidence intervals are reported for estimation of parameters and all tests of significance are two-tailed at an alpha of 0.05 .

\section{Results}

Less than $4 \%$ of data were missing. Punjab had significantly higher conformity scores in all core-functions (Figure 2 and Figure 3, Table 1), key components, and essential attributes (Figure 1) overall, and at district lev$\mathrm{el}$, with $\mathrm{t}$-tests $\mathrm{t}(4120,0.05)$ values ranging from -22.4 to -36.58, all $P$ values < 0.001 , and Cohen's $d$ values ranging from 1.2 (District level) to 0.7 (Essential Attribute level).

Overall, only $27.8 \%$, 95\% Confidence Interval [26.4, 29.2] of indicators were classifiable as acceptably prepared to manage a crisis situation, $50 \%(48.5,51.5)$ as partially, and $22.2 \%(20.9,23.5)$ as inadequately prepared at districts level. Among the five districts with overall conformity scores in the acceptable category of preparedness, two were from Khyber Pakhtunkhwa, with scores of 86.0 and 85.0\% while three were from Punjab, with scores 80.0, 78.0 , and $72 \%$.

One third of the KP districts had conformity scores evaluated as inadequately prepared, ranging from 18 to 22\%; none of the Punjab districts fell in this category. Only one district out of the least prepared $60 \%$ was from Punjab. In Khyber Pakhtunkhwa $16.7 \%(15.3,18.1)$ of indicators at district level were in the acceptable category, $50 \%(48.1,51.9)$ in partially, while $33.3 \%(31.5,35.1)$ were in the inadequately prepared range while in Punjab, 50\% $(47.3,52.7)$ fell in acceptably and the other $50 \%$ in partially prepared categories.

None of the six Core Functions of the WHO Health Systems Framework achieved a score more than 54\% while for half of these (Health Workforce, Health Financing, and Service Delivery) it was less than 50\%. The highest scores were observed in the Leadership and Governance: $53.6 \%(52.4,54.9)$, and Health Information: $52.5 \%(50.7,54.4)$ functions, while the lowest were in Service Delivery: $46.9 \%(45.7,48.1)$ and Health Workforce: $46.7 \%(43.1,50.3)$.

None of the 16 Key Components achieved a score at acceptable level of preparedness, while two were in the inadequate preparedness category: Emergency Medical Services and Mass-casualty Management, 34.4\% (27.6, 41.20), and National and subnational strategies for financing health-sector emergency management, 30.9\% $(26.5,35.3)$. The key component Medical supplies and equipment for emergency response operations had an overall conformity score of $51.7 \%$, with $61 \%(56,66)$ of indicators assessed as partially or inadequately prepared.

Four Essential Attributes, out of a total of 51 (27), achieved scores at acceptable level of preparedness: National structure for multisectoral emergency management and coordination, 72.2\% (64.5, 79.9), Prevention and control of communicable diseases and immunization, $69.4 \%$ (57.5, 81.3), National committee

\begin{tabular}{|c|c|c|c|c|}
\hline Function & $\begin{array}{c}\text { Overall } \\
\text { Mean(SD) } \\
{[95 \% \mathrm{CI}]}\end{array}$ & $\begin{array}{c}\text { Khyber Pakhtunkhwa } \\
\text { Mean(SD) } \\
{[95 \% \text { CI] }}\end{array}$ & $\begin{array}{c}\text { Punjab } \\
\text { Mean(SD) } \\
{[95 \% \text { CI }]}\end{array}$ & $P$-value \\
\hline 1. Leadership and Governance & $\begin{array}{l}53.6(23.8) \\
{[52.4,54.9]}\end{array}$ & $\begin{array}{l}44.3(23.4) \\
{[42.8,45.8]}\end{array}$ & $\begin{array}{l}72.3(9.0) \\
{[71.4,73.1]}\end{array}$ & $<0.001$ \\
\hline 2. Health Workforce & $\begin{array}{l}46.7(25.5) \\
{[43.1,50.3]}\end{array}$ & $\begin{array}{c}37.5(19.4) \\
{[34.2,40.8]}\end{array}$ & $\begin{array}{l}65.2(26.5) \\
{[58.6,71.7]}\end{array}$ & $<0.001$ \\
\hline $\begin{array}{l}\text { 3. Medical Products, Vaccines and } \\
\text { Technology }\end{array}$ & $\begin{array}{l}51.8(30.8) \\
{[48.7,54.8]}\end{array}$ & $\begin{array}{l}38.4(28.1) \\
{[35.0,41.8]}\end{array}$ & $\begin{array}{c}78.4(13.9) \\
{[76.0,80.8]}\end{array}$ & $<0.001$ \\
\hline 4. Health Information & $\begin{array}{l}52.5(23.8) \\
{[50.7,54.4]}\end{array}$ & $\begin{array}{l}48.2(24.2) \\
{[45.9,50.5]}\end{array}$ & $\begin{array}{l}61.2(20.5) \\
{[58.4,64.0]}\end{array}$ & $<0.001$ \\
\hline 5. Health Financing & $\begin{array}{l}31.0(25.2) \\
{[26.5,35.4]}\end{array}$ & $\begin{array}{l}25.6(21.8) \\
{[20.8,30.3]}\end{array}$ & $\begin{array}{c}41.7(28.1) \\
{[32.9,50.4]}\end{array}$ & $<0.001$ \\
\hline 6. Service Delivery & $\begin{array}{l}46.9(23.1) \\
{[45.7,48.1]}\end{array}$ & $\begin{array}{l}40.3(23.0) \\
{[38.8,41.7]}\end{array}$ & $\begin{array}{l}60.1(16.8) \\
{[58.6,61.6]}\end{array}$ & $<0.001$ \\
\hline
\end{tabular}


Figure 1 Overall health system preparedness for crisis management in two provinces of Pakistan

Proportions of essential attributes of Healthcare Systems Framework Core functions at different levels of preparedness

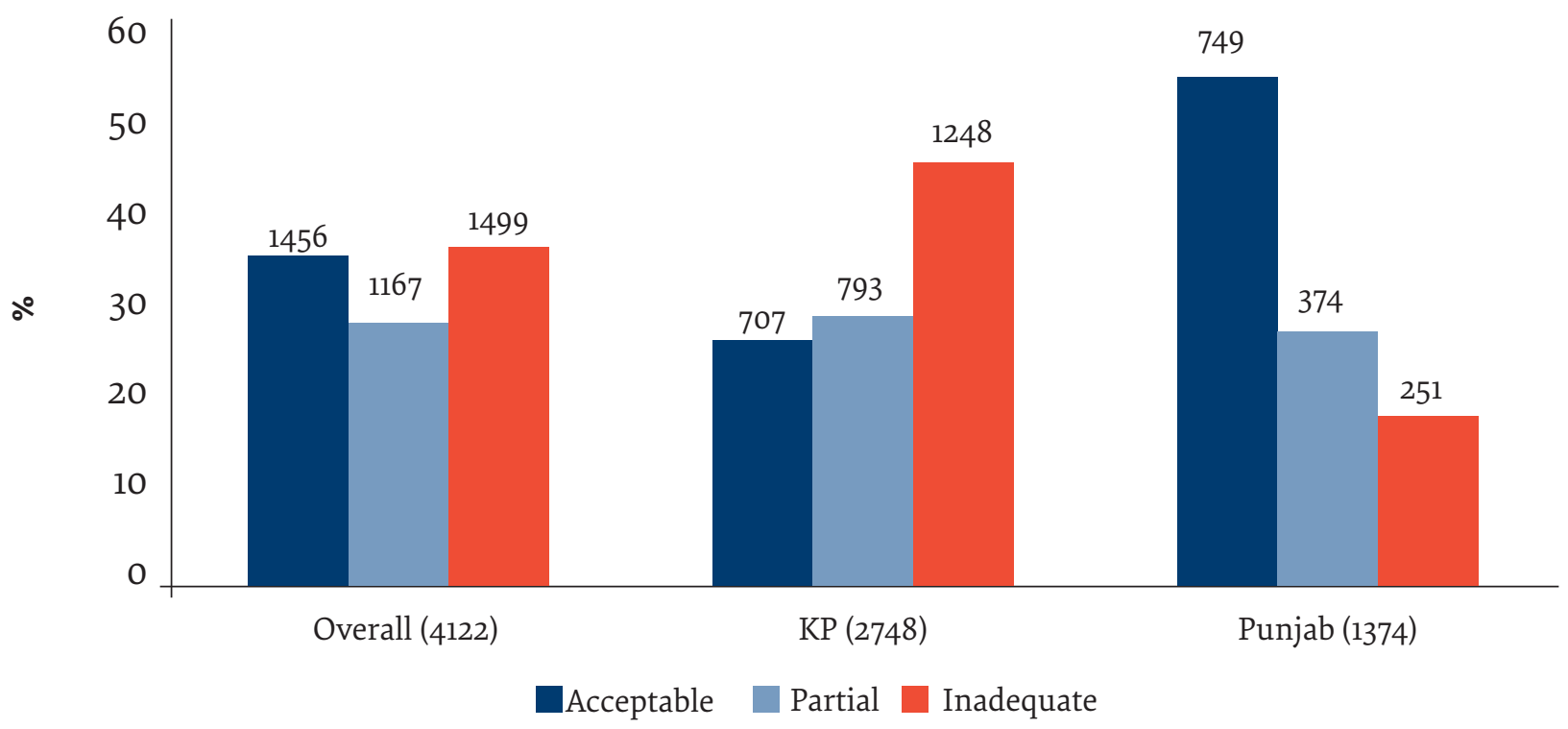

Figure 2 Comparison of the levels of preparedness between the two provinces in the six core functions of WHO Health Systems Frameworks

Means and 95\% confidence intervals for Conformity scores in the six core functions of WHO Health Systems Framework

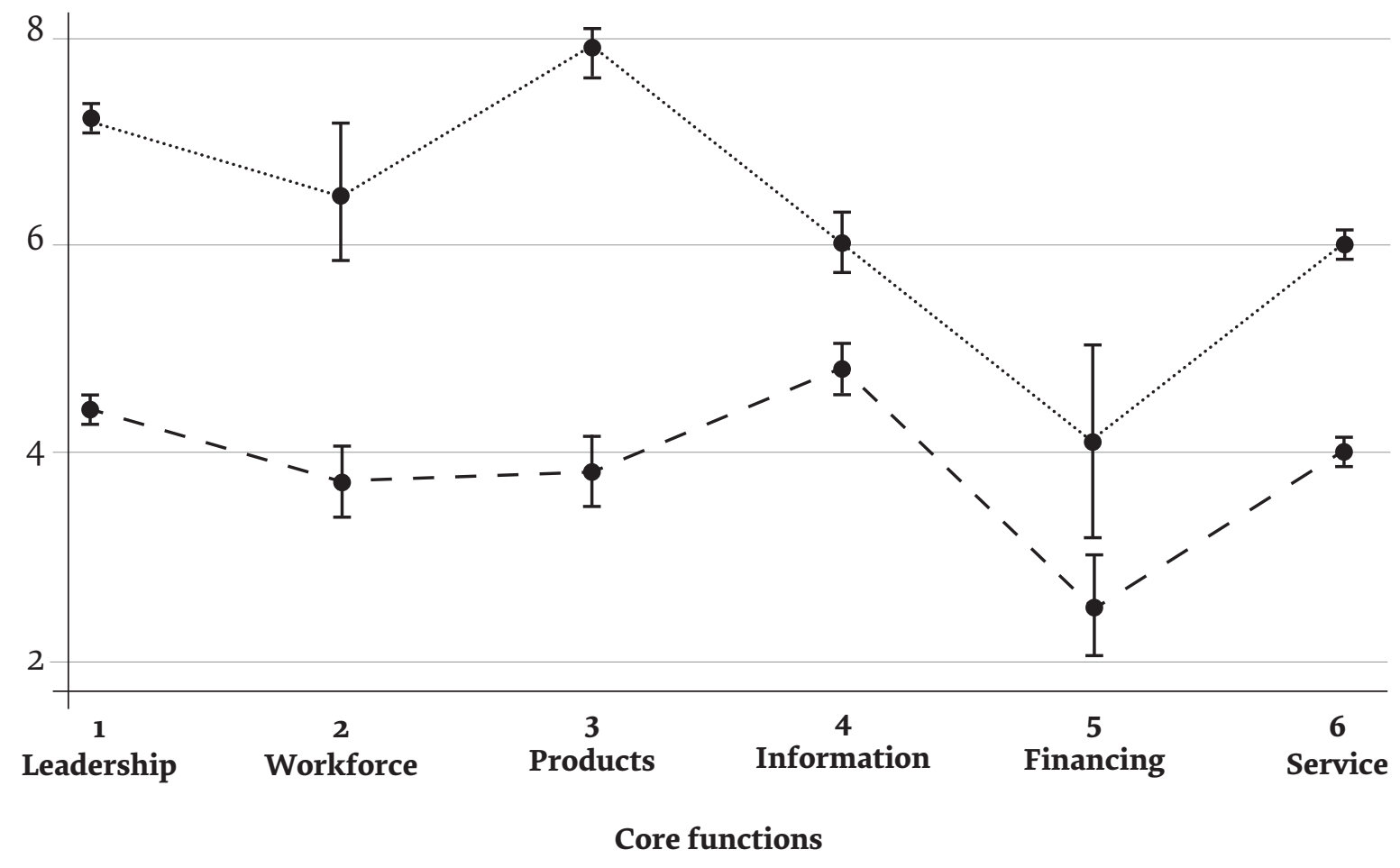

Mean 95\% Cls: Punb

$\mathbf{K P}--\mathbf{-}$ 


\section{Figure 3 Comparison of scores out of the total possible in main components of WHO Health Systems Framework between the} studied districts

District wise status of preparedness in the six Core Functions of the WHO Health Systems Framework

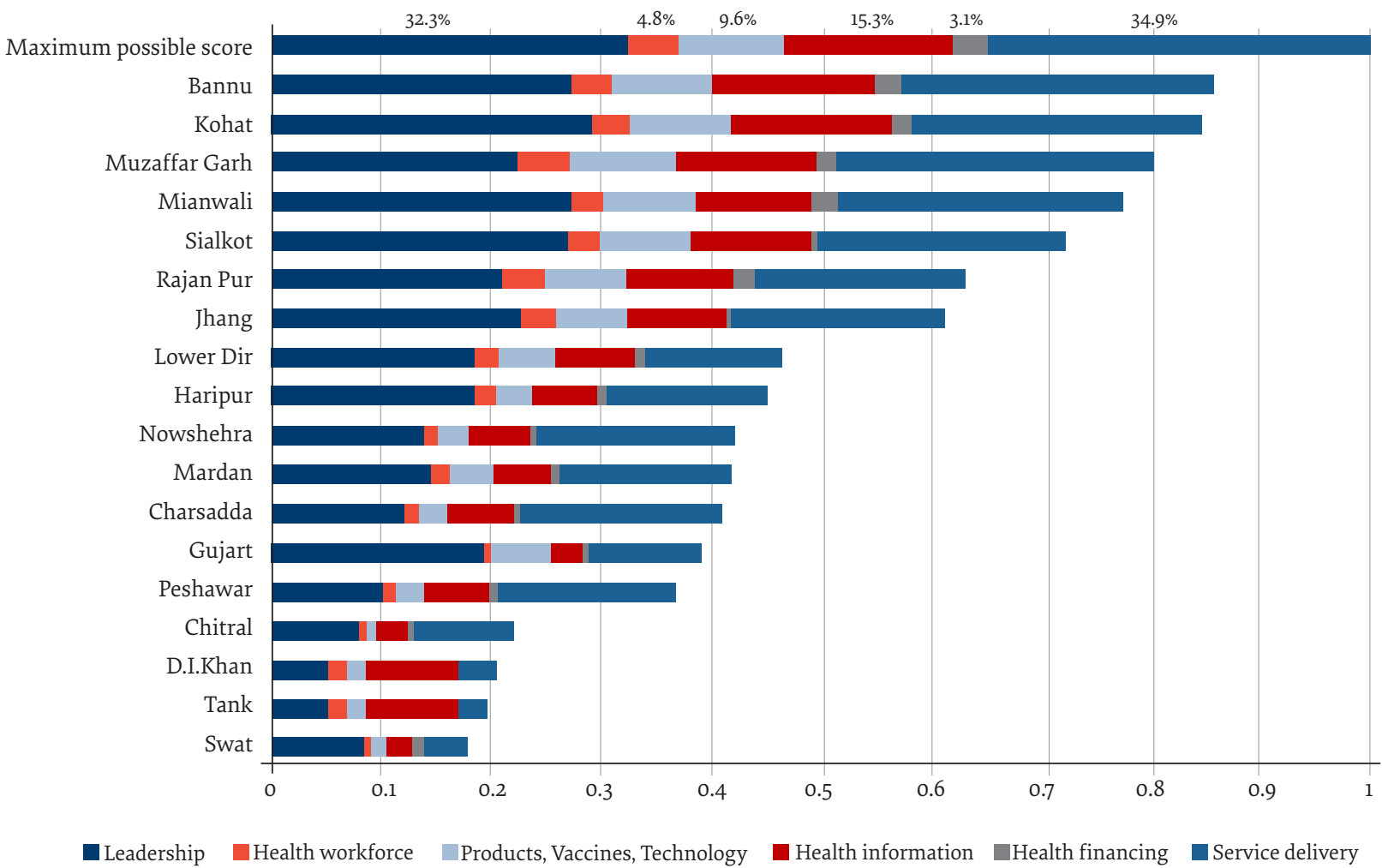

for multisectoral emergency management, 67.1\% (61.0, 73.2), and Mother-and-child health-care and reproductive health, 66.7\% $(53.6,79.8)$. All of the attributes with scores in acceptable category either predominantly evaluated structure (three out of four), or were equivocal in assessment stance.

Six Essential Attributes had scores in inadequately prepared category: Research and evidence base, $18.5 \%$ (10.6, 26.4), Health-sector financing mechanisms, $24.3 \%$ (17.3, 31.3), Management of situations involving mass fatality and missing persons, 27.8\% (23.1, 32.5), Emergency telecommunications, $32.6 \%(25.2,40.0)$, Capacity for mass-casualty management, $34.4 \%(27.5,41.3)$, and Nutrition and food safety, $34.7 \%(23.6,45.8)$. All of the attributes in the inadequately prepared category either predominantly evaluated process (five out of six), or were equivocal in evaluation stance.

The difference of scores achieved in the six core functions of the WHO Health Systems Framework was statistically significant (Kruskal-Wallis $\chi^{2}$ (5) = $140.61, P<0.001, \varepsilon 2=0.1)$. Post hoc tests revealed all the 15 pairwise comparisons to be significant except two: Health Workforce versus Service Delivery (Difference: -0.423, $P=0.336)$, and Medical Products versus Health Information (Difference: $-0.645, P=0.260$ ). Difference of conformity scores between primary healthcare and other system components was not significant $(\mathrm{t}(4120)=0.044$, $P=0.965)$.

\section{Discussion}

The use of a validated instrument administered by trained personnel from the relevant areas of expertise lends credibility to this evaluation. With less than $30 \%$ of district-level indicators classifiable as acceptably prepared, the level of preparedness in these most vulnerable areas of a disaster prone country is almost half of that reported for locales (28) at very low levels of vulnerability (15). Development of human resources, training and education was second only to health system financing mechanisms in lack of preparedness. Health workforce ultimately channels all invested resources to the end recipient and any deficiency in this area will have system-wide implications.

Among the 13 Essential Attributes belonging to the Leadership and Governance function, which scored the highest among the six components while still being less than 54\% compliant, the most prominently deficient attribute was Research and Evidence base, followed by Programmes on Emergency Preparedness and Risk Reduction. These components can be construed as predominantly process indicators. This is in stark contrast with the fact that the highest scoring attributes in this function were National Structures and Committees for Emergency Management and Coordination - both indicators of elements of structure. An entity scoring the highest in the domain of structure and the lowest 
in the functionality of that same structure may reflect management issues. As the study did not include any covariates of preparedness, no light can be shed on the possible causal mechanisms behind this structurefunction divide.

In the core function with the second highest preparedness, Health Information, the most deficient were the attributes of strategies for risk communication with the public and the staff during operations, other than information sharing at national and international levels. The three attributes of this function scoring the highest were Surveillance System, Emergency Reporting System, and Multisectoral Initial Rapid Assessment, all predominantly structure-related or equivocal indicators. For the third place holding core function, Medical Products, Vaccines, and Technology the highest scores were for the Supply, while the lowest ones were in Services.

For the fourth next highest scoring function, Service Delivery, the highest scores were again in the indicators construable as predominantly structure-related: Communicable Disease and Immunization, Maternal and Child Health, and Health Services for displaced persons, while the lowest were in the capacity for masscasualty management, emergency telecommunications, and management of situations involving mass fatality and missing persons; all of which indicators assess aspects of process and function. The fifth highest scoring core function, Health Workforce, had both attributes, Development of Human Resources and Training and Education, almost at par ( 48 \& 46\% respectively) regarding lack of preparedness, both indicators of process. The least prepared function, Health Financing, has two components, Multi-sectorial Mechanisms of Financing $\&$ Health-sector Financing, both concerning function rather than structure.

\section{Conclusions}

The study detected, in addition to a poor overall preparedness of health system for crisis management, a consistent pattern of poorer performance in the process, coordination, and operational aspects compared to the structural elements.

\section{Limitations}

The findings cannot be generalized to the whole country as the evaluation was limited to high-risk districts. Lack of information on covariates precludes elucidation of causal mechanisms.

\section{Recommendations}

Leadership and Governance function: Research and ev- idence base being the least compliant attribute of this function, strengthening collaboration regarding applied research between academic and the disaster management institutions is called for.

Health Workforce Function: Development of human resources, training \& education attributes were found to be partially prepared. Health workforce development, preferably though skilled partnerships like that with the WHO, should be strengthened.

Medical Products, Vaccines, and Technology Function: All four attributes of this function were partially prepared. Up to $61 \%$ of indicators in the medical supplies key component showed inadequate or partial availability of emergency provisions. The finding needs confirmation through further studies as such supplies are usually among the first items on any aid initiative. Ensuring ongoing provision of locale-specific requirements must be prioritized appropriately.

Health Information Function: The most deficient attributes were strategies for risk communication to the public and to the field staff. This Achilles' heel of the whole disaster management system needs urgent attention of decision makers and researchers.

Health Financing Function: Health sector financing mechanisms was the least compliant attribute in this function. Agencies managing federal and provincial budgetary and contingency fund allocation must take notice.

Service Delivery Function: Preparedness for mass fatality and missing persons' management, emergency telecommunications, capacity for mass casualty management, and nutrition and food safety were all among the least compliant attributes within this function. NDMA and other relevant agencies should address this issue on priority basis.

Protocol development for implementation of crisis management plans and ongoing periodic assessment of preparedness status with dissemination of results to the relevant quarters must be made part of the disaster management mechanisms in the country. System barriers must be identified and leverage for fundamental solutions to this structure-function schism must be sought.

Further studies based on random selection of areas and including data on covariate profiles are required to elucidate determinants of preparedness. Moreover, studies for assessment at district management and primary healthcare levels are recommended, especially regarding area-specific emergency reserves.

Funding: WHO Pakistan office funded the study without any role in data collection or analysis.

Competing interests: None declared. 


\section{Préparation du système de santé pakistanais à la gestion de crise : étude transversale Résumé}

Contexte : Depuis plus de deux décennies, l'Organisation mondiale de la Santé (OMS) recommande vivement que les systèmes de santé soient prêts à gérer efficacement les situations de crise à l'échelle mondiale. Le Pakistan est connu pour son importante vulnérabilité face aux risques et pour son manque de capacités de réaction et d'adaptation. La préparation des systèmes de santé dans les zones présentant un profil de risque élevé est essentielle. On observe cependant que très peu d'études sont consacrées à l'état de cette préparation dans le pays.

Objectifs : La présente étude avait pour objet d'évaluer l'état de préparation des composantes du système de santé pour la gestion de crise dans les districts du Pakistan les plus exposés aux catastrophes.

Méthodes : Un échantillon choisi à dessein de 12 des districts les plus exposés aux catastrophes dans deux provinces du Pakistan a été évalué pour ce qui concerne la préparation, à l'aide des outils de l'OMS destinés à évaluer la capacité du système de santé en matière de gestion de crise. Six fonctions essentielles du cadre des systèmes de santé, comprenant un total de 229 indicateurs, ont été évaluées, au niveau de la gestion par les districts ainsi que par les établissements de soins de santé secondaires et tertiaires. Les indicateurs pris en compte exprimés en proportions ont été calculés afin d'évaluer le niveau de préparation considéré comme étant acceptable ( $\geq 66 \%$ ), partiel (36-65\%) ou insuffisant $(\leq 35 \%)$.

Résultats : Soixante-douze pour cent (intervalle de confiance à $95 \%=46,0,90,0$ ) des indicateurs dans ces districts les plus vulnérables présentaient un niveau de préparation partiel ou insuffisant pour assurer une gestion appropriée des crises. Même la fonction essentielle, Leadership et Gouvernance, dont le score était le plus élevé, présentait un niveau de préparation partielle, avec un résultat de 53,6 \% [52,4,54,9]. L'étude a montré que le niveau de préparation des éléments de processus était moindre que celui des composantes de structure.

Conclusions : Au niveau fédéral, la planification stratégique, la mise en œuvre, la gestion et le suivi visant à assurer la préparation des systèmes de santé doivent être révisés et renforcés.

$$
\begin{aligned}
& \text { تأهب النظام الصحي في باكستان لإدارة الأزمات: دراسة تقييمية مقطعية } \\
& \text { ضياء الحق، بشار ات حسين شاه، محمد أرداكاني، سعيد أكبر خان، سليم محمد، سعيد فاروق، ساردار حيات خان، قدسية هدى }
\end{aligned}
$$

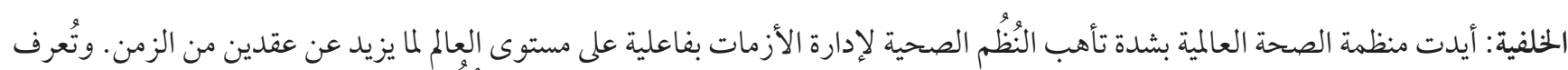

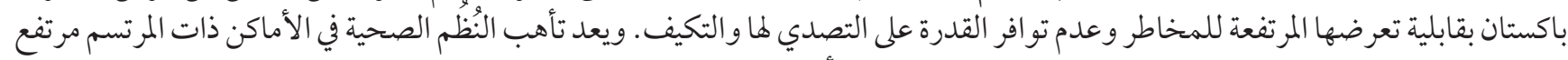

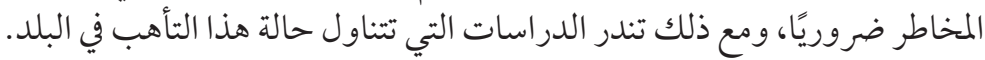
الأهداف: هدفت هذه الدر اسة إلى تقييم حالة تأهب عناصر النظام الصحي لإدارة الأزمات في أكثر المناطق المعرضة للكو ارث في باكستان.

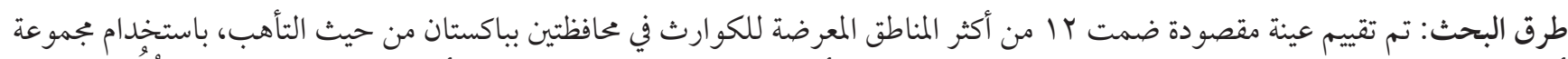

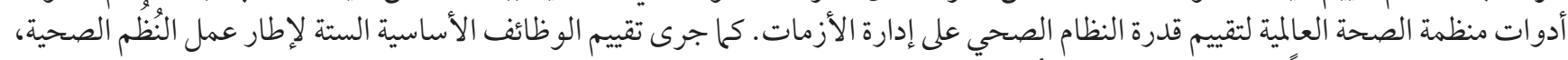

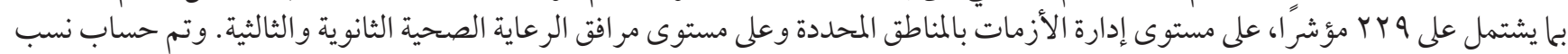

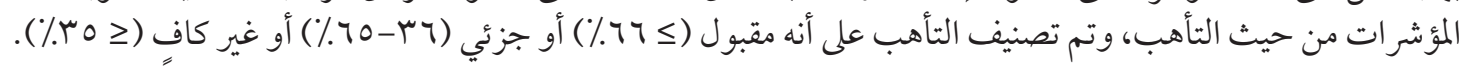

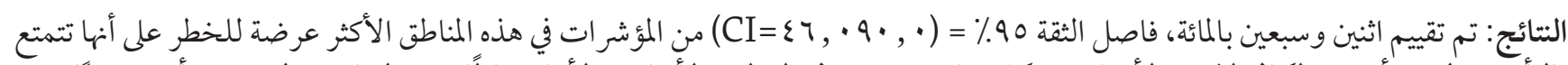

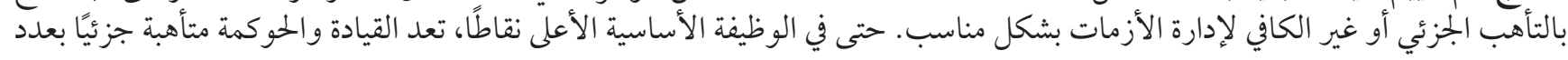

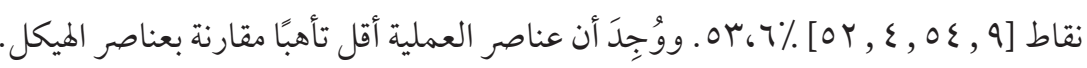

الاستنتاجات: يجب استعر اض وتعزيز التخطيط الاستر اتيجي على المستوى الاتحادي، و التنفيذ، والإدارة، و المتابعة التي تهدف إلى ضمان تأهب النُظم 


\section{References}

1. United Nations Office for Disaster Risk Reduction. Terminology on Disaster Risk Reduction. International Strategy for Disaster Reduction (ISDR) 2009 (http://www.unisdr.org/files/7817_UNISDRTerminologyEnglish.pdf).

2. World Health Organization Regional Office for Europe. Strengthening health-system emergency preparedness: Toolkit for assessing health-system capacity for crisis management. Copenhagen: WHO Regional Office for Europe; 2012 (http://www.euro. who.int/en/publications/abstracts/strengthening-health-system-emergency-preparedness.-toolkit-for-assessing-health-system-capacity-for-crisis-management.-part-1.-user-manual-2012).

3. United Nations. United Nations Plan of Action on Disaster Risk Reduction for Resilience: Towards a Risk-informed and Integrated Approach to Sustainable Development. New York: United Nations; 2016. (http://www.preventionweb.net/files/49076_unplanofaction.pdf).

4. United Nations. Sendai Framework for Disaster Risk Reduction 2015 - 2030. New York: United Nations; 2015. (http://www.wcdrr. $\operatorname{org} /)$.

5. CRED. Center for Research on Epidemiology of Disasters. School of Public Health, Université Catholique de Louvain. OttigniesLouvain-la-Neuve: Université Catholique de Louvain; 2017 (http://www.cred.be)./)

6. World Health Organization. WHO's Work in Emergency Risk and Crisis Management. Geneva: World Health Organization; 2016. (http://apps.who.int/iris/bitstream/10665/251551/1/WHO-WHE-ERM-EXT-2016.4-eng.pdf?ua=1).

7. United Nations Development Program. Human Development Report 2016: Human Development for Everyone. New York: UNDP; 2016. (http://hdr.undp.org/sites/default/files/2016_human_development_report.pdf).

8. The World Bank. Disaster Risk Management in South Asia: A Regional Overview. Washington, DC: The World Bank; 2012 (http:// documents.worldbank.org/curated/en/648281468170977802/Disaster-risk-management-in-South-Asia-regional-overview).

9. Muni SD. Conflicts in South Asia: Causes, consequences, prospects. Institute of South Asian Studies; 2013 Mar 26. Report No.: 170-26 March 2013. (https://www.files.ethz.ch/isn/162720/ISAS_Working_Paper_170_-_Conflicts_in_South_Asia_26032013170324. pdf).

10. Pakistan Bureau of Statistics. Provincial Summary Results of 6TH Population and Housing Census-2017. Islamabad: Pakistan Bureau of Statistics; 2018. (http://www.pbs.gov.pk/content/provisional-summary-results-6th-population-and-housing-census-2017-0).

11. Asian Development Bank. Islamic Republic of Pakistan: Country Environment Analysis. 2008. (https://www.adb.org/sites/default/files/institutional-document/32193/country-environment-analysis.pdf).

12. Khan H, Khan A. Natural hazards and disaster management in Pakistan. Munich Personal RePEc Archive 2008 (https://mpra. ub.uni-muenchen.de/11052/1/NATURAL).

13. World Health Organization. Pakistan Health Situation Report \# 1. Geneva: World Health Organization; 2015 (http://www.who. int/hac/crises/afg/afghanistan_earhquake_26october2015.pdf?ua=1).

14. National Disaster Management Authority. Multi-sector Initial Rapid Assessment Report. 2014 Sep 20. (http://www.ndma.gov.pk/ publications/Smira_2014.pdf).

15. Birkmann J, Welle T. The WorldRiskIndex 2016: Reveals the Necessity for Regional Cooperation in Vulnerability Reduction. J of Extr Even. 2016;3(1). https://doi.org/10.1142/S2345737616500056

16. South Asian Intelligence Report. Fatalities in Terrorist Violence in Pakistan 2003-2017. South Asia Terrorism Portal 2017 (http:// www.satp.org/satporgtp/countries/pakistan/database/casualties.htm).

17. United Nations Development Programme. Disaster Risk Reduction in Pakistan. New York: UNDP; 2017 (http://www.pk.undp. org/content/dam/pakistan/docs/CPRU/Disaster\%20Risk\%20Management/Project\%2obrief\%20-\%20Disaster\%20Risk\%20Reduction\%20in\%20Pakistan.pdf).

18. Gaiha R. Natural Disasters in South Asia. 2010. Report No.: ASARC Working Paper 2010/o6. (https://crawford.anu.edu.au/acde/ asarc/pdf/papers/2010/WP2010_06.pdf).

19. United Nations General Assembly. Report of the open-ended intergovernmental expert working group on indicators and terminology relating to disaster risk reduction. New York: United Nations; 2017. https://www.preventionweb.net/files/50683_oiewgreportenglish.pdf).

20. United Nations General Assembly. Session 44 Resolution 236. 989 Dec 22. Report No.: A/RES/44/236. (http://www.un.org/ga/ search/view_doc.asp?symbol=A/RES/44/236).

21. UNISDR. The United Nations Office for Disaster Risk Reduction. (https://www.unisdr.org/who-we-are/mandate).

22. United Nations Office for Disaster Risk Reduction. What is Disaster Risk Reduction. New York: United Nations; 2017 (https:// www.unisdr.org/who-we-are/what-is-drr).

23. CARER. Center for Advanced Research in Emergency Response. Emergency Response Systems: Concepts, features, evaluation and design. 2011 (http://liu.diva-portal.org/smash/get/diva2:507142/FULLTEXTo1.pdf).

24. World Health Organization Regional Office for the Eatern Mediterranean (WHO/EMRO). Health System Profile: Pakistan. Cairo: WHO/EMRO; 2007. (http://apps.who.int/medicinedocs/documents/s17305e/s17305e.pdf). 
25. National Action Plan for the Implementaon of Bangkok Principles on Health Aspects of the Sendai Framework for Disaster Risk Reduction. 2017. (http://www.nheprn.gov.pk/userfiles1/file/policies/20171215NationalActionPlan.pdf).

26. National Disaster Management Authority. National Disaster Management Plan: Main Volume. 2012. (http://www.ndma.gov.pk/ plans/NDMP-Main\%2oVol.pdf).

27. World Health Organization Regional Office for Europe. Toolkit for assessing health-system capacity for crisis management: Part I; User Manual. Copenhagen: World Health Organization Regional Office for Europe; 2012 (http://www.euro.who.int/_data/ assets/pdf_file/0008/157886/e96187.pdf).

28. Djalali A, Della CF, Foletti M, Ragazzoni L, Ripoll GA, Lupescu O, et al. Art of disaster preparedness in European union: a survey on the health systems. PLoS Curr. 2014 Dec 17;6. https://doi.org/10.1371/currents.dis.56cf1c5c1bodeae1595a48e294685d2f

29. Bayntun C, Rockenschaub G, Murray V. Developing a health system approach to disaster management: A qualitative analysis of the core literature to complement the WHO Toolkit for assessing health-system capacity for crisis management. PLoS Curr 2012 Aug 22;4:e5028b6037259a. https://doi.org/10.1371/5028b6037259a

30. World Health Organization Regional Office for Europe. Toolkit for assessing health-system capacity for crisis management: Part II; Assessment form. Copenhagen: World Health Organization Regional Office for Europe; 2012 (http://www.euro.who. int/_data/assets/pdf_file/oo10/157888/eg6188.pdf).

31. Stata Statistical Software. Release 14 [computer program]. College Station, TX: StataCorp LP.; 2015. 